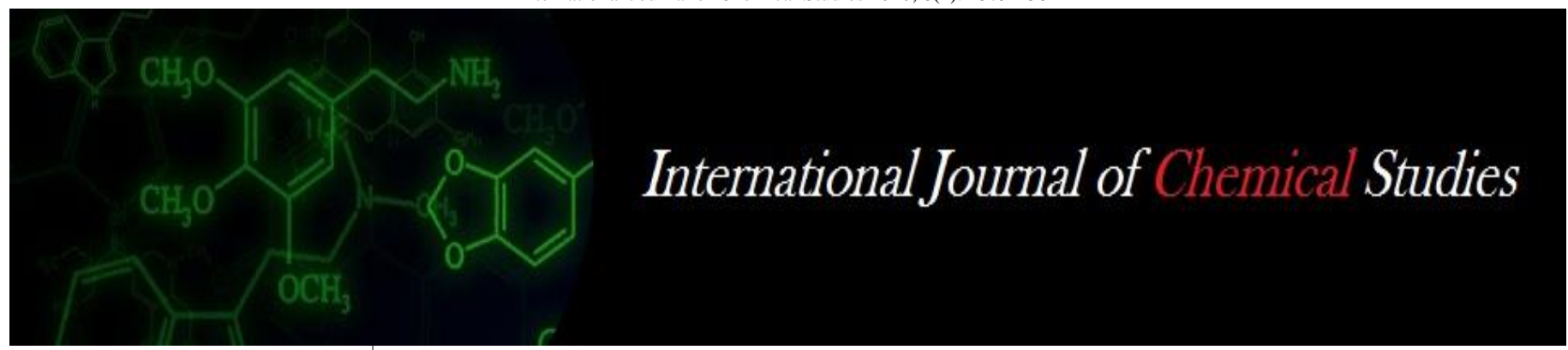

P-ISSN: 2349-8528

E-ISSN: 2321-4902

IJCS 2020; 8(1): 2579-2582

(C) 2020 IJCS

Received: 19-11-2019

Accepted: 21-12-2019

\section{RK Jhade}

Jawaharlal Nehru Krishi

Vishwavidyalaya, Krishi Vigyan

Kendra, Chandannagar,

Chhindwara, Madhya Pradesh,

India

Ghanshyam Deshmukh

Jawaharlal Nehru Krishi

Vishwavidyalaya, Krishi Vigyan

Kendra, Chandannagar,

Chhindwara, Madhya Pradesh,

India

\section{PL Ambulkar}

Jawaharlal Nehru Krishi

Vishwavidyalaya, Krishi Vigyan

Kendra, Chandannagar,

Chhindwara, Madhya Pradesh,

India

\section{SL Alawa}

Jawaharlal Nehru Krishi

Vishwavidyalaya, Krishi Vigyan

Kendra, Chandannagar,

Chhindwara, Madhya Pradesh,

India

\section{Corresponding Author:}

\section{RK Jhade}

Jawaharlal Nehru Krishi

Vishwavidyalaya, Krishi Vigyan

Kendra, Chandannagar,

Chhindwara, Madhya Pradesh,

India

\section{Impact of plant growth regulators on yield and yield attributing characters in pomegranate (Punica granatum L.) cv. Bhagwa in Satpura plateau region of Madhya Pradesh}

\author{
RK Jhade, Ghanshyam Deshmukh, PL Ambulkar and SL Alawa
}

DOI: $\underline{\text { htps://doi.org/10.22271/chemi.2020.v8.i1am.8657 }}$

\begin{abstract}
Pomegranate (Punica granatum L.) is one of the famous table fruits mainly cultivated in tropical and sub-tropical eco-system. It is a newly introduced as alternate commercial fruit crop against Nagpur mandarin in Chhindwara district of Satpura plateau region of M.P. during 2012. One of the major problems under this condition is that $\mathrm{cv}$. Bhagwa exhibits heavy flowering and fruit drop by increasing the fruit set and fruit retention. Plant growth regulators are reported to play a significant role in pomegranate (Chaudhari and Desai, 1993). Hence, an attempt has been made to find suitable growth regulators and their doses for improving fruit set and yield in pomegranate cv. Bhagwa under Satpura plateau region. The experiment was conducted on pomegranate orchard at JNKVV, Krishi Vigyan Kendra, Chhindwara (M.P.) India during Ambia crop (Jan-Feb) 2018 on 6-year old Bhagwa planted at a spacing of $12 \times 8 \mathrm{ft}$. The experiment was laid out in Randomized Block Design with four replications, and two plants per replication. There were seven treatments with three growth regulators, viz., NAA at $10,15 \mathrm{ppm} ; \mathrm{GA}_{3}$ at $10,15 \mathrm{ppm}$ and 2,4-D at $10,15 \mathrm{ppm}$ and control were sprayed three times starting at $50 \%$ flowering stage and, subsequently, at 20 days' interval. The parameters like average weight of fruit, number of fruits/tree and yield per plant and yield MT/ha. were significantly influenced by the application of plant growth regulators at various intervals. Results revealed that application of NAA at 15 ppm gave significantly high fruit set which resulted in highest fruit yield of $10.5 \mathrm{~kg} / \mathrm{plant}$ at the age of 6 years, as against $5.21 \mathrm{~kg}$ in the control. Fruit weight and quality improved significantly due to growth regulator sprays.
\end{abstract}

Keywords: Pomegranate, Bhagwa, plant growth regulators, yield

\section{Introduction}

Pomegranate (Punica granatum L.) is one of the famous table fruit mainly cultivated in tropical and sub-tropical eco-system. It is shrub commercially grown for its sweet and slight acidic fruit mainly used for dessert purpose (Hays, 1953). In India, pomegranate is commercially cultivated in Maharashtra, Karnataka and Andhra Pradesh and the most important cultivar in this pomegranate belt is 'Bhagwa' which covers around $80 \%$ area under pomegranate in Maharashtra. Since last two decades, its cultivation has popularized in arid and semi-arid regions of India, not only because of its sweet acidic taste, precocious bearing and better shelf-life but as a remunerative crop as well. Among various arid fruits, pomegranate occupies second largest area after ber. The importance of synthetic plant growth regulators in achieving higher yield and better quality of horticultural crop has been well recognized in recent time. Plant growth regulators have given encouraging results in case of pomegranate fruit crop (Anawal, et al. 2015) ${ }^{[1]}$. However, practically, there has been very little work done on use of plant growth regulators in pomegranate crop. The plant growth regulators (PGR) act as messengers and are needed in small quantities at low concentrations. Generally their site of action and biosynthesis are different. Most of the plant growth regulators exhibit a broad spectrum and thus a single PGR may influence several entirely different processes. Moreover, plant growth regulators enhance the rapid changes in physiological and biochemical characters and improve crop productivity. Those among agricultural practices which may increase the fruit production and improve the quality of several other fruit crops are the applications of plant growth regulators, especially gibberellic acid. 
Gibberellic acid has been reported to influence vegetative growth, flowering, fruiting and various disorders in many fruit crops. Although these references are available in the literature and efforts have been improve fruit quality by applying of plant growth Regulators.

It is a newly introduced as alternate commercial fruit crop against Nagpur mandarin in Chhindwara district of Satpura plateau region of M.P. during 2012. One of the major problems under this condition is that cv. Bhagwa exhibits heavy flowering and fruit drop by increasing the fruit set and fruit retention. Hence, an attempt has been made to find suitable growth regulators and their doses for improving fruit set and yield in pomegranate cv. Bhagwa under Satpura plateau region. The main objectives of present study was to assess the yield parameters influenced by application of various plant growth regulators.

\section{Material and Method}

The experiment was carried out on Pomegranate orchard at JNKVV, Krishi Vigyan Kendra, under the agroclimatic conditions of Chhindwara (M.P.) India during Ambia crop (Jan-Feb) 2018 on 6-year old Bhagwa planted at a spacing of $12 \times 8 \mathrm{ft}$. In a view to give proper bahar treatment to the plants water stress was given to the plants. During the bahar treatment the cultural operations like ploughing, hoeing, cleaning, training, spraying were undertaken. At initiation of bahar, the recommended dose of manures and fertilizers were applied to each plant and light irrigation was given. Regular irrigation was given afterwards through drip irrigation system. The experiment was laid out in a Randomized Block Design with four replications, and two plants per replication. There were seven treatments with three growth regulators, viz., $\mathrm{NAA}$ at 10, $15 \mathrm{ppm} ; \mathrm{GA}_{3}$ at 10, $15 \mathrm{ppm}$ and 2,4-D at 10, 15 ppm and control trees were sprayed three times starting at $50 \%$ flowering stage and, subsequently, at 20 days interval.

The plant growth regulators were applied by foliar spray with the fine sprayer. Care was also taken to avoid spray of one solution over other treatments. The spray was washed with the clean water after the application of every solution of plant growth regulator.

\section{Naphthaleneacetic acid (NAA)}

NAA is a synthetic auxin plant hormone that is routinely used for the vegetative propagation of plants from stem and cutting. The effect of NAA on plant growth is greatly dependent on the time of admission and concentration. NAA has been shown to greatly increase cellulose fiber formation in plants. In majority of fruit plants fruit drop is controlled by spraying of NAA in different fruit crops in different concentration. It is applied after blossom fertilization. Ghosh et al. (2012) ${ }^{[6]}$ application of different doses of NAA @ 15, 20, 25 and 30ppm and observed that sprayed of NAA at 15 ppm was the most effective in reducing the fruit drop at different months after fruit set which resulted in doubling of fruit production as compared to control and improved fruit size in sweet orange.

\section{Gibberellic acid (GA3)}

Gibberellins control fruit development in various ways and at different developmental stages. Fruit development is a complex and tightly regulated process. Growing fruits are very active metabolically and act as strong sinks for nutrients with hormones possibly modulating the process (Brenner and Cheikh, 1995) ${ }^{[2]}$. The development of a fruit can be separated into phases that include pre-pollination, pollination, fertilization and fruit set, post fruit set, ripening and senescence. The successful fertilization of the ovule is followed by cell division and cell expansion resulting in the growth of the fruit. Gibberellins are known to influence both cell division and cell enlargement. Reddy and Prasad (2012) [11] reported that the spray with GA3 75ppm has increased fruit size and yield in pomegranate cv. Ganesh. Khalid et al. (2012) ${ }^{[7]}$ working in young 'Kinnow' mandarin found that the spray of gibberellic acid $10 \mathrm{ppm}$ at fruit setting stage and their effect on fruit quality was evaluated immediately after harvest.

\section{2, 4-Dichlorophenoxyacetic acid (2, 4-D)}

Endogenous hormones and their balance play a modulating role in the mobilization of nutrients to the developing organs and can influence the longevity of a bud. The dependence of abscission relative to the endogenous content of auxins has been proven by exogeneous application of 2, 4-D or NAA, as the transportation of auxins by the plant lasts for a long time without ethylene appearing to affect it. Reddy and Prasad (2012) ${ }^{[11]}$ reported that application of 2, 4-D at 20, 30 and 40 ppm three times starting at full bloom and, subsequently, at 45 and 90 days after fruit set in pomegranate cv. Ganesh, has resulted significantly increased fruit size in length, breadth and volume and higher fruit weight $(262.23 \mathrm{~g})$, higher aril percent and maximum number of fruits (64.00) which resulted in highest fruit yield of $16.78 \mathrm{~kg} / \mathrm{plant}$.

Table 1: PGR Concentration and Time of application

\begin{tabular}{|c|c|c|c|c|c|}
\hline Treatments & PGRs & Concentrations (ppm) & \multicolumn{3}{|c|}{ Time of Application } \\
\hline $\mathrm{T}_{1}$ & NAA & 10 & $50 \%$ Flowering & Subsequently at 20 days & Subsequently at 40 days \\
\hline $\mathrm{T}_{2}$ & NAA & 15 & $50 \%$ Flowering & Subsequently at 20 days & Subsequently at 40 days \\
\hline $\mathrm{T}_{3}$ & $\mathrm{GA}_{3}$ & 10 & $50 \%$ Flowering & Subsequently at 20 days & Subsequently at 40 days \\
\hline $\mathrm{T}_{4}$ & $\mathrm{GA}_{3}$ & 15 & $50 \%$ Flowering & Subsequently at 20 days & Subsequently at 40 days \\
\hline $\mathrm{T}_{5}$ & $2,4-\mathrm{D}$ & 10 & $50 \%$ Flowering & Subsequently at 20 days & Subsequently at 40 days \\
\hline $\mathrm{T}_{6}$ & $2,4-\mathrm{D}$ & 15 & $50 \%$ Flowering & Subsequently at 20 days & Subsequently at 40 days \\
\hline $\mathrm{T}_{7}$ & Control & - & - & - & - \\
\hline
\end{tabular}

\section{Result and Discussion}

\section{Average weight of fruit (g)}

The data presented in Table 2 and fig 1 which revealed the results the treatment $\mathrm{T} 4$ recorded significantly maximum weight of fruit (282.22g) which was (27.05\%) more as compared to control. The minimum weight of fruit $(222.12 \mathrm{~g})$ was recorded in treatment $\mathrm{T} 7$ control. The beneficial effects of GA3 in increasing weight of fruit seems to be through enhanced rapid mobilization of food reserves from the plant during the vegetative growth by gibberllic acid. This might also be due to more accumulation of food material and increase in size of fruit as well as fruit weight which was positively correlated with fruit size. The present results obtained through spraying of GA3 are in accordance with Gajarmal (2014), Reddy (2010), Lal and Ahmed (2013) [10, 12, 8]. 


\section{No. of fruits per plant}

Number of fruit per plant had significantly influence due to foliar application of various plant growth regulators. Treatment T2 i.e. spraying of NAA $(15 \mathrm{ppm})$ recorded maximum number of fruit per plant (40.42) which was 32.74 per cent more as compared to control treatment. The minimum number of fruit per plant was recorded in treatment $\mathrm{T} 7$ i.e. control (30.45). The beneficial effects of NAA in increasing number of fruits per plant seems and fruit drop is controlled by spraying of NAA in different fruit crops in different concentration. It is applied after blossom fertilization. Ghosh et al. (2012) [6] application of different doses of NAA @ 15, 20, 25 and 30ppm and observed that sprayed of NAA at $15 \mathrm{ppm}$ was the most effective in reducing the fruit drop at different months after fruit set which resulted in doubling of fruit production as compared to control and improved fruit size in sweet orange.

\section{Weight of fruit per plant $(\mathrm{kg})$}

Weight of fruit per plant had significantly influenced due to foliar application of various plant growth regulators. Treatment $\mathrm{T}_{4}$ recorded maximum weight of fruit per plant $(10.20 \mathrm{~kg})$ which was 50.89 per cent more as compared to control treatment. The lowest weight of fruit per plant was recorded in treatment T7 i.e. control $(6.76 \mathrm{~kg})$. Weight of fruit should be positively correlated with weight of fruit per plant.

\section{Yield (Mt/ha)}

The data presented in Table 2 which revealed the results obtained for weight of fruit per plant had significantly influenced due to foliar application of various plant growth regulators. Treatment T4 i.e. spraying of NAA (15 ppm) recorded maximum yield per hector $(8.74 \mathrm{mt} / \mathrm{ha})$ which was 55.24 cent more as compared to control. The lowest yield per hectare was recorded in treatment T7 i.e. control $(5.63 \mathrm{mt} / \mathrm{ha})$. The rigid cell wall becomes softened and its plasticity (irreversible capacity to stretch) increases. The loosening of cell wall begins due to dissolution of cell wall material, breaking of chemical bonds between cellulose and other cell wall materials, and fresh synthesis of new cell wall material and its incorporation into existing cell wall. The loosening of cell wall decreases the wall pressure (WP) which is equal to turgor pressure (TP). This action causes greater uptake of water and increase in the size of vacuole; and cell stretches resulting in increasing the yield contributing characters. Our findings are in agreement with those of Reddy (2010) ${ }^{[12]}$ in pomegranate.

Table 2: Effect of PGR Concentrations on Yield attributes in pomegranate cv. Bhagwa

\begin{tabular}{|c|c|c|c|c|}
\hline Treatments & Av. weight of fruit(g) & No. of fruits/plant & Weight of fruit/plant (kg) & Yield t/ha \\
\hline $\mathrm{T}_{1}-(\mathrm{NAA} 10 \mathrm{ppm})$ & $252.33(13.60)$ & $37.76(24.01)$ & $9.53(40.98)$ & $7.94(41.03)$ \\
\hline $\mathrm{T}_{2}-(\mathrm{NAA} 15 \mathrm{ppm})$ & $259.72(16.92)$ & $40.42(32.74)$ & $10.5(55.33)$ & $8.74(55.24)$ \\
\hline $\mathrm{T}_{3}-\left(\mathrm{GA}_{3} 10 \mathrm{ppm}\right)$ & $273.58(23.16)$ & $36.91(21.22)$ & $10.10(49.41)$ & $8.41(49.38)$ \\
\hline $\mathrm{T}_{4}-\left(\mathrm{GA}_{3} 15 \mathrm{ppm}\right)$ & $282.22(27.05)$ & $36.14(18.69)$ & $10.20(50.89)$ & $8.49(50.80)$ \\
\hline $\mathrm{T}_{5}-(2,4-\mathrm{D} 10 \mathrm{ppm})$ & $254.21(4.44)$ & $37.29(22.46)$ & $9.48(40.24)$ & $7.89(40.14)$ \\
\hline $\mathrm{T}_{6}-(2,4-\mathrm{D} 15 \mathrm{ppm})$ & $261.02(7.51)$ & $37.62(23.55)$ & $9.82(45.27)$ & $8.18(45.29)$ \\
\hline $\mathrm{T}_{7}-(\mathrm{Control})$ & 222.12 & 30.45 & 6.76 & 5.63 \\
\hline S.E \pm & 18.70 & 4.43 & 1.77 & 0.98 \\
\hline CD at 5\% & NA & 13.31 & 5.31 & 2.95 \\
\hline
\end{tabular}

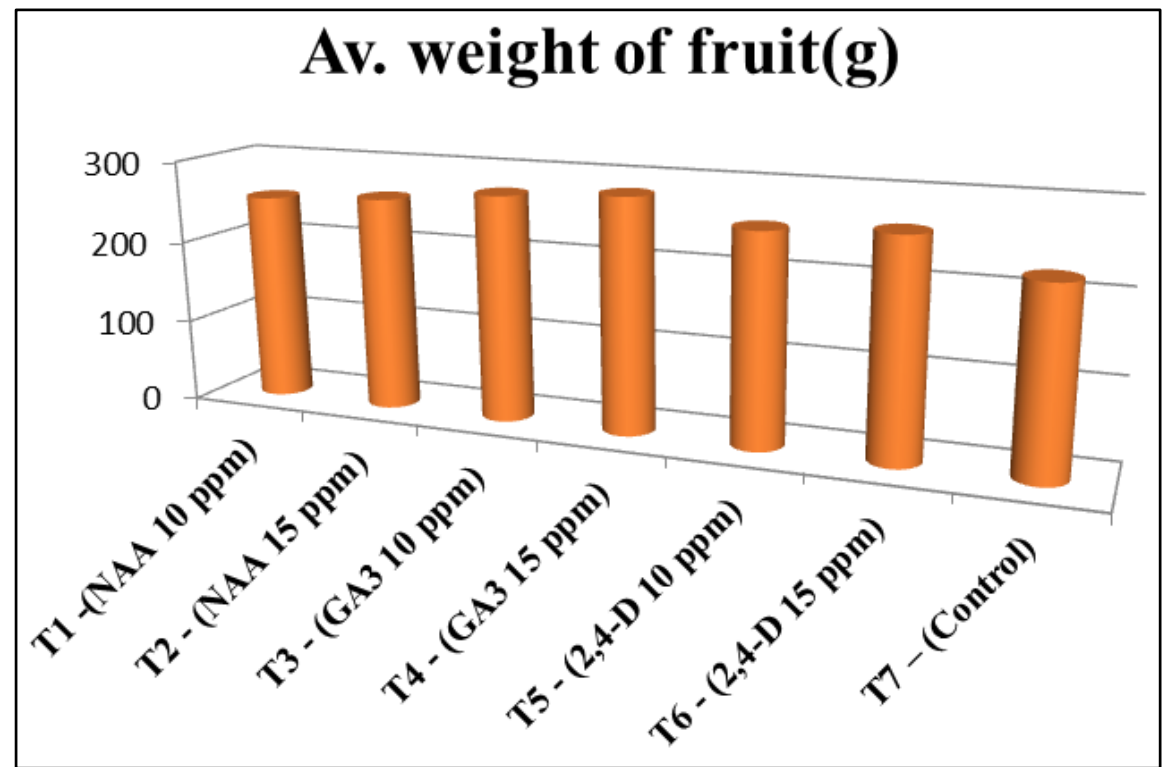

Fig 1: Effect of PGR Concentrations on average fruit weight (g) in pomegranate cv. Bhagwa

\section{Conclusions}

In summing up the present investigation based on obtained results, all plant growth regulators application positively influenced fruit attributes and yield of pomegranate fruits as compared to control. Among all treatments NAA@ @ $15 \mathrm{ppm}$ produced highest yield of pomegranate fruits. In nut shell, it can be concluded that foliar application of NAA at $15 \mathrm{ppm}$ gave significantly high fruit set which resulted in highest fruit yield of $10.5 \mathrm{~kg} /$ plant at the age of 6 years, as against $6.76 \mathrm{~kg}$ in the control at the time of $50 \%$ flowering and subsequently 20 and 40 days was beneficially in producing higher yield and yield attributing characters. Fruit weight and quality improved significantly due to growth regulator sprays. 


\section{References}

1. Anawal VV, Narayanaswami P, Ekabote SD. effects of plant growth regulators on fruit set and yields of pomegranate $\mathrm{cv}$. Bhagwa. International Journal of Scientific Research. 2015; 9(4):220-222.

2. Brenner ML, Cheikh $\mathrm{N}$. The role of hormones in photosynthate partitioning and seed filling. In: Davies PJ (ed), Plant Hormones: Physiology, Biochemistry and Molecular Biology, Kluwer Academic Publishers, Dordrecht, 1995, 649-670.

3. Ghosh SN, Chattopadhyay N, Hore JK, Munsi, PS. Effect of bio-regulators on fruit retention, yield and qualitative characteristics of sweet orange. Sustainable Agriculture in Sub-humid zone, 1995, 177-179.

4. Gaikwad PS, Tambe TB, Gaonkar YA. Effect of foliar application of chemicals on yield of pomegranate cv. Bhagwa, International Journal of Chemical Studies. 2019; 7(1):524-528

5. Gajarmal KS. Effect of plant growth regulators on yield and quality of pomegranate (Punica granatum) cv. Bhagwa. M.Sc. Thesis submitted to Department of Horticulture, VNMKV, Parbhani, 2014.

6. Ghosh SN, Bera B, Roy S. Influence of plant growth regulators on fruit production of sweet orange. J Crop \& Weed. 2012; 8(2):83-85

7. Khalid S, Malik AU, Khan AS, Jamil A. Influence of exogenous applications of plant growth regulators on fruit quality of Young 'Kinnow' Mandarin (Citrus nobilis $\times$ C. deliciosa) Trees. Int. J Agric. Biol. 2012; 14(2):229234.

8. Lal S, Ahmed N. Yield and quality attributes of pomegranate under karewa environment of Kashmir valley as affected by pre-harvest chemicals application. Progressive Horticulture. 2012; 44(1):157-165.

9. Mahaveer Suman, Pency D Sangma, Deva Ram Meghawal, Om Prakash Sahu. Effect of plant growth regulators on fruit crops, Journal of Pharmacognosy and Phytochemistry. 2017; 6(2):331-337

10. Pawar PS, Jagtap DD, Garad BV, Shirsath HK. Effect of plant growth regulators on maturity, yield and fruit weight of pomegranate cv. Mridula. Adv. Pl. Sci. 2005; 18:167-170.

11. Reddy PA, Prasad DM. Effect of plant growth raguletors on fruit characters and yield of pomegranate (Punica granatum L.) cv. Ganesh. Int. J. P. A. E. Sci. 2012; 2(2):2331-4490.

12. Reddy PA. Effect of plant growth regulators on yield and quality of pomegranate cv. Ganesh. M.Sc. thesis submitted to Andhra Pradesh Horticultural University, 2010 .

13. Suman MD, Sangm P, Meghawal DR, Sahu OP, Sahu P. Effect of plant growth regulators on fruit crops. Journal of Pharmacognosy and Photochemistry. 2017; 6(2):331337. 